\title{
Situs Candi Sambisari Yang Pernah Terpendam
}

\section{Masyhudi}

Keywords: description, geology, volcanic, archaeology, site, hindu-buddha, temple

\section{How to Cite:}

Masyhudi, nfn. (2005). Situs Candi Sambisari Yang Pernah Terpendam. Berkala Arkeologi, 25(1), 31-45. https://doi.org/10.30883/jba.v25i1.908

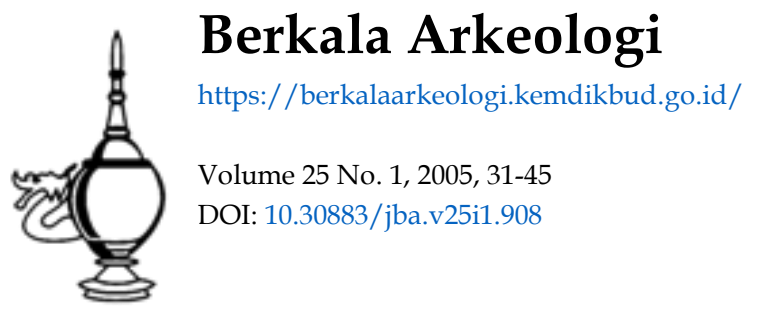

\section{c) (1) (5)}

This work is licensed under a Creative Commons Attribution-NonCommercial-ShareAlike 4.0 International License. 


\title{
SITUS CANDI SAMBISARI YANG PERNAH TERPENDAM
}

\author{
Oleh : Masyhudi
}

\section{Pendahuluan}

\section{A. Latar Belakang}

Sambisari adalah nama sebuah dusun di Kelurahan Purwomartani, Kecamatan Kalasan, Kabupaten Sleman, Propinsi Daerah Istimewa Yogyakarta. Daerah ini baru dikenal sebagai situs pada tahun 1966, yaitu ketika seorang petani sedang mencangkul dan secara kebetulan membentur batu candi yang sebelumnya tak terduga sama sekali. Batu itu ternyata puncak dari sebuah candi. Gugusan Candi Sambisari tertimbun oleh lahar dari Gunungapi Merapi setinggi 6,5 meter, yang datang dari Sungai Kuning. Sungai tersebut terletak kira-kira 300 meter di sebelah barat candi. Kompleks candi Sambisari terdiri atas sebuah candi utama dan tiga buah candi perwara yang dibuat dari batu andesit, dengan pagar keliling dari batu putih berukuran $50 \mathrm{~m}$ x $48 \mathrm{~m}$. Selain pagar itu, ada pula dua pagar keliling di luarnya.

Candi utama berada di sebelah timur dengan pintu masuk di barat, berukuran $13,65 \mathrm{~m} \times 13,65 \mathrm{~m}$, tinggi $7,5 \mathrm{~m}$. Di dalam bilik candi terdapat

dengan lingga-yoni, menghadap ke utara. Pada dinding luar tubuh candi, terdapat relung yang berisi arca. Di sisi candi bagian barat terdapat dua relung yang terletak di kanan dan kiri pintu masuk, yang seharusnya berisi arca Mahakala dan Nandicwara, tetapi kini arcanya sudah hilang. Di sisi candi bagian

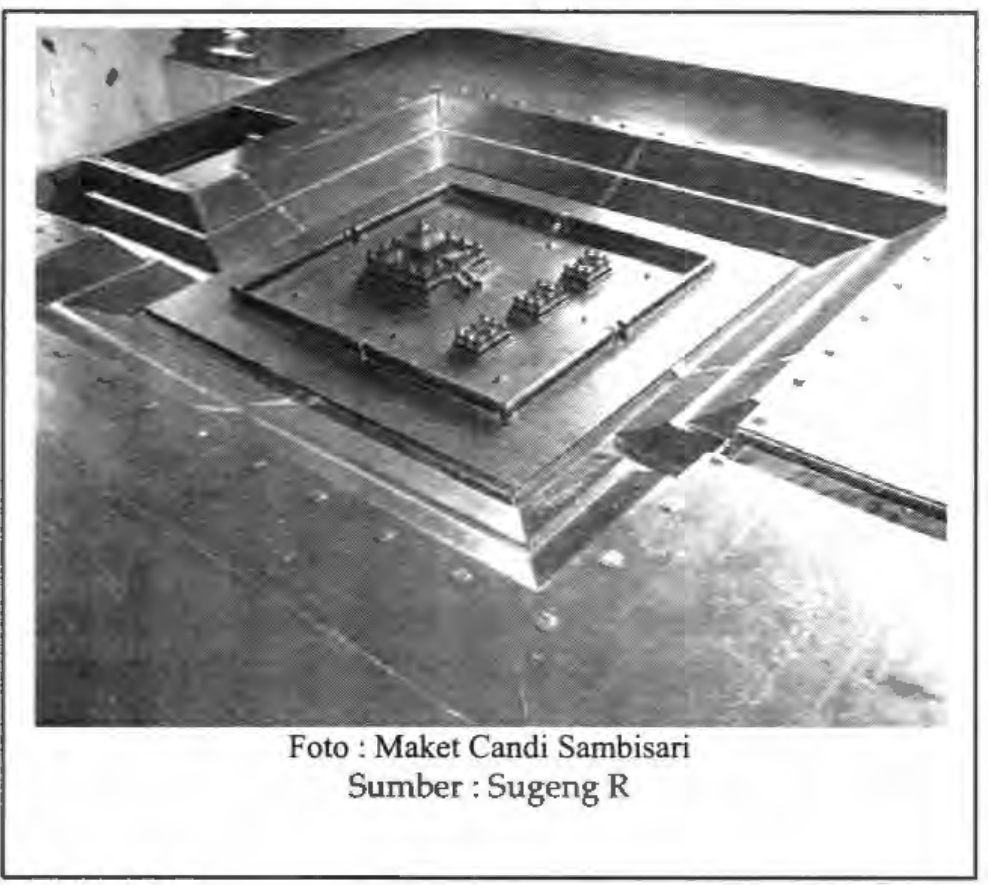
selatan terdapat arca Agastya, sisi timur terdapat arca Ganeca, dan sisi utara berisi arca Durga Mahisasuramardini. Hal yang menarik dari candi ini ialah kaki bangunannya seolah-olah tidak ada, karena alas bangunan (basement) berfungsi pula sebagai kaki candi. Menarik pula bahwa pada lantai selasar terdapat 12 batu umpak ( 8 berbentuk bulat, 4 berbentuk persegi), yang mungkin dahulu dipakai 
sebagai alas tiang yang dibuat dari kayu, sebagai penopang atap. Di bawah beberapa umpak ditemukan mangkuk perunggu, dan antara lain terdapat prasasti dari lempengan emas yang jika diamati dari bentuk hurufnya berasal dari abad IX. Candi perwara berjumlah tiga buah berada di depan candi utama, tinggal bagian kaki dengan ukuran masing-masing $4,80 \mathrm{~m}$ x 480 meter, $490 \mathrm{~m}$ x $480 \mathrm{~m}$, dan $480 \mathrm{~m} \times 480 \mathrm{~m}$. Cukup menarik perhatian, bahwa pada halaman candi tertanam sejumlah lingga yang berfungsi sebagai patok-patok batas. Demikian juga titik pusat halaman candi berada di sebelah selatan tangga masuk candi induk.

Situs ini merupakan contoh dari situs percandian yang pernah tertimbun oleh lahar Gunung Merapi yang datang melalui Kali Kuning yang terletak tidak jauh dari situs.

Permukaan tanah (maaiveld) aslinya terletak 6,5 meter di bawah permukaan tanah sekarang. Berdasarkan hasil pengamatan dapat diketahui bahwa gugusan candi ini ternyata belum selesai dikerjakan oleh para pembuatnya (Anonim, 1989)

\section{B. Permasalahan}

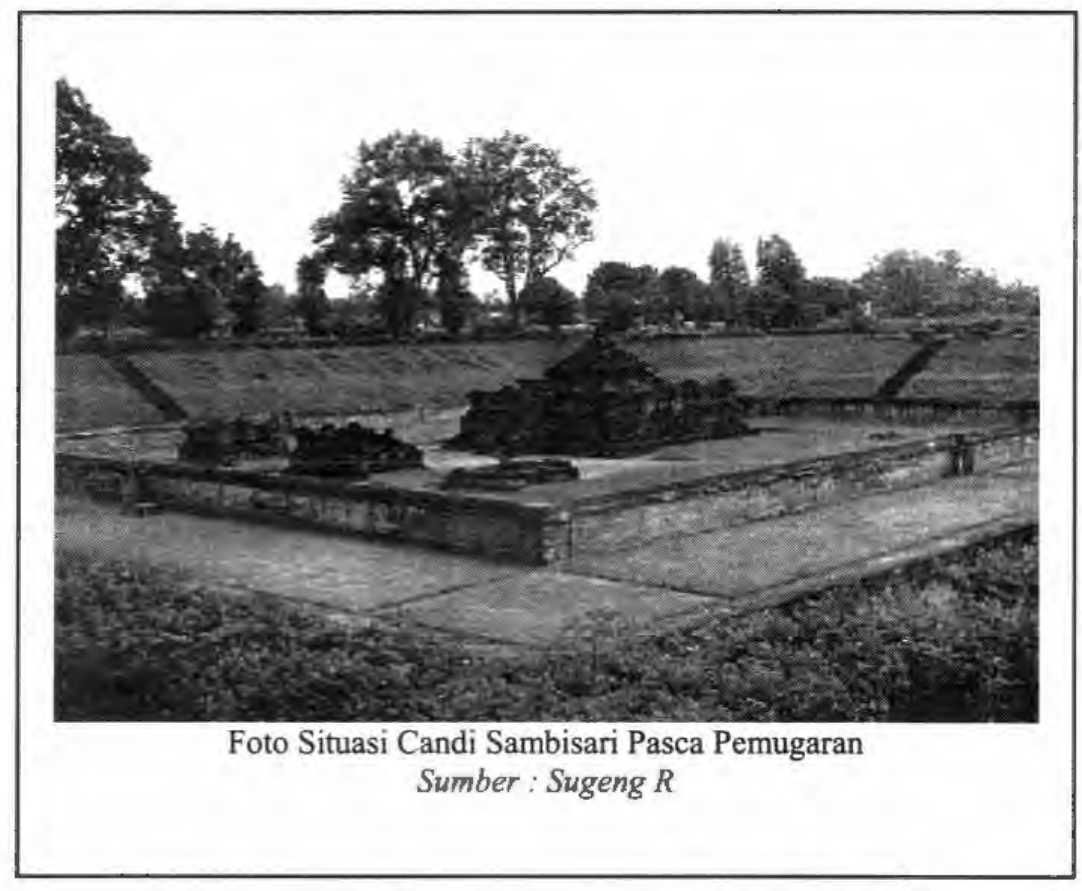

Dalam pembuatan atau pendirian suatu bangunan suci, ada dua hal penting yang harus diperhatikan, yaitu mengenai pemilihan lahan atau tempat berdirinya bangunan dan pengujian tanahnya. Dalam kitab ManasraSilpasastra dijelaskan tentang cara pemilihan lahan sebagai lokasi pendirian suatu bangunan suci (kuil atau candi) yang terdiri dari dua tahap. Tahap pertama, memperhatikan lebih dahulu kondisi tanah dengan pengamatan atas unsur-unsur fisik yang terdiri dari kontur, warna, bau, rupa, rasa, sentuhan, kerataan permukaan, dan sifat tetumbuhan. Tahap kedua adalah melakukan pengujian terhadap tanah secara rinci (Mundardjito, 1993 : 240). 
Keberadaan Candi Sambisari, hingga sekarang masih menyimpan banyak hal yang belum diketahui, antara lain kapan bangunan candi tersebut didirikan, siapa (raja) yang mendirikan, dan apa alasan pendiriannya. Memang telah dilakukan berbagai usaha, terutama melalui diskusi dan penelitian oleh para peneliti sesuai dengan segala keterbatasan yang ada. Akan tetapi, nampaknya untuk memperoleh keseragaman pendapat serta untuk menambah khazanah pengetahuan di bidang arkeologi perlu terus diupayakan kegiatan-kegiatan tersebut, guna mengungkap informasi sebanyak mungkin tentang keberadaan Candi Sambisari.

Dalam kaitannya dengan pemilihan lahan tempat untuk suatu bangunan candi (Sambisari) perlu juga diketahui bagaimana geomorfologinya, hal ini didasari oleh keberadaan Candi Sambisari yang pernah terpendam oleh lahar, akibat letusan Gunung Merapi yang terletak di sekitar $18 \mathrm{~km}$ di sebelah utara candi.

Tulisan ini bertujuan untuk mengetahui bentuk lahan tempat berdirinya bangunan Candi Sambisari, terutama yang terkait dengan aspek spasial dan lingkungannya. Oleh karenanya, melalui pendekatan geomorfologi, diharapkan dapat diketahui sebab-sebab Candi Sambisari terpendam yang baru diketahui pertengahan kedua abad ke-20.

\section{Kondisi Lingkungan Situs Candi Sambisari}

\section{A. Ekologi}

Pada dasarnya arkeologi adalah ilmu yang berbicara tentang kebudayaan. Dalam perspektif ekologis, Leslie White lah yang mempelopori bahwa lingkungan sebagai salah satu penyebab munculnya tipe kebudayaan tertentu. Ia menjelaskan bahwa proses perkembangan kebudayaan mengacu pada gejala yang bersifat ekologis, yaitu menempatkan lingkungan sebagai salah satu faktor yang sangat menentukan dalam proses evolusi kebudayaan (Leslie A White, 1959; Ibnu Thufail, 1994). Sementara itu, Steward mejelaskan, bahwa lingkungan tidak secara langsung terkait dengan seluruh unsur kebudayaan. Tetapi, karakteristik lingkungan secara langsung mempengaruhi mata pencaharian atau subsistence system.

Ekologi adalah istilah yang pernah dicetuskan oleh Reiter pada tahun 1865, yaitu ilmu yang memiliki hubungan antara organisme dan lingkungan secara keseluruhan (Mc. Naughton dan Wolf, 1990), kemudian disempurnakan oleh Emest Haeckle, tahun 1869, yaitu suatu keseluruhan pengetahuan yang berkaitan dengan hubungan antara organisme dengan lingkungan, baik yang organik maupun anorganik secara total (Resosoedarmo dkk, 1984). 
Environmental Archaeology atau arkeologi lingkungan merupakan bagian dari arkeologi (Archaeology Science), yaitu sebagai suatu ilmu yang membutuhkan ilmu lain yang terkait, seperti geologi, biologi, arkeometri dan lain sebagainya, karena adanya hubungan antara manusia dengan lingkungannya yang sangat kompleks (Shackley, 1981). Di sisi lain ilmu lingkungan telah mengintegrasikan berbagai ilmu yang mempelajari hubungan antara jasad hidup, termasuk manusia dengan lingkungannya (Soeriaatmadja, $1979: 1$ ). Konsep-konsep ekologi sangat berguna bagi arkeologi, yaitu sebagai suatu pendekatan yang heuristik untuk memikirkan sistem keterkaitan antara faktor budaya dan alam. Penggunaan konsep ekosistem telah banyak memberikan implikasi positif bagi arkeologi. Seorang arkeolog dapat melakukan pengujian terhadap aspek-aspek tingkah laku yang berhubungan dengan interaksinya dalam lingkungan. Oleh karenanya, antara arkeologi dan ekologi terdapat suatu komitmen, yaitu konsep ekosistem yang menunjukkan variabelitas spasial atau pun temporal dan hubungan yang kopmpleks sebagai suatu elemen yang penting pada suatu penelitian (Schiffer, 1986).

Antara manusia dan lingkungan masa lalu telah lama terjalin hubungan dan telah lama pula dipelajari oleh para arkeolog. Sehingga, banyak prinsip lingkungan (ekologi) yang diterapkan dalam penelitian arkeologi (Mundardjito, 1993 dalam Hardesty, 1980). Munculnya konsep dasar yang terkandung dalam definisi arkeologi lingkungan disebabkan oleh perkembangan arkeologi dan lama kelamaan para arkeolog menyadari bahwa data arkeologi yang diperoleh tidak hanya dengan ciri-ciri yang terkandung di dalam benda atau situs arkeologi saja, tetapi juga dapat diperoleh dari adanya hubungan antara benda atau situs arkeologi dengan lingkungannya. Dalam upaya mendapatkan spesifikasi yang lebih tepat mengenai hubungan antara manausia dengan suatu proses alam tertentu yang terangkum dalam suatu analisis yaitu ekosistem, perlu adanya suatu pendekatan ekologi. Bugi Kusumohartono 1985 dalam Damon, 1977 menyebutkan bahwa ekologi adalah the sum total of physical feature and organisms occuring in a given area and their interaction (Kusumohartono, 1985 : 61). Dengan demikian dalam konsep ekosistem menekankan adanya saling ketergantungan antara komunitas organisme dengan situasi alam tempat komunitas tersebut.

Pertimbangan faktor ekologi yang digunakan orang untuk memenuhi kebutuhannnya, baik yang berkenaan dengan perolehan makanan dan perlindungan diri maupun penempatan dirinya dengan penempatan bangunan untuk tempat menyelenggarakan kegiatan adalah suatu upaya pemanfaatan sumberdaya lingkungan dalam rangka memenuhi kebutuhan manusia. Hal demikian dapat diketahui melalui data arkeologi berupa situs-situs yang mengandung kumpulan artefak, ekofak, dan bangunan dalam satu konteks. 


\section{B. Geomorfologi}

Dalam suatu kajian ilmu pengetahuan yang terkait dengan lingkungan di permukaan bumi, geomorfologi sebagai salah satu ilmu tentang kebumian mempunyai arti serta peranan yang cukup penting. Untuk bidang arkeologi, terutama yang terkait dengan aspek spasial dan lingkungan akan selalu memperhatikan dan memperhitungkan kesesuaian suatu lahan. Bentuk lahan yang unsur-unsurnya antara lain terdiri dari relief, topografi, material penyusun dan proses geomorfik dalam geomorfologi adalah sangat relevan untuk memahami karakteristik dan keberadaan situs-situs arkeologi. Untuk memperkirakan distribusi spasial dari situs, mengidentifikasi wilayah yang kemungkinan mengandung temuan arkeologis dapat digunakan suatu pendekatan terpadu, yaitu parsial dan geomorfologis. Di samping itu, dalam suatu kajian arkeologi, untuk memperoleh data tentang lingkungan dapat digunakan dengan peta geomorfologi yang memperlihatkan satuan-satuan bentuk lahan, tanah, batuan, kemampuan tanah, air tanah, dan ketinggian, kelerengan (Mundardjito, 2002).

Sebagaimana disebutkan di atas, bahwa proses geomorfik dalam geomorfologi merupakan sesuatu yang sangat relevan untuk memahami karakteristik dan keberadaan situs-situs arkeologi. Proses geomorfologi adalah semua proses fisikal, kimia dan biologi yang mengakibatkan adanya perubahan bentuk bumi, yang dalam hal ini ada dua jenis proses, yaitu proses eksogen dan proses endogen.

1. Proses Eksogen

Dalam proses eksogen terdapat tiga macam aktivitas, yaitu degradasi, agradasi, dan tindakan organisme. Dalam proses eksogen ini pada hakekatnya bertujuan untuk meratakan muka bumi. Pada awalnya degradasi atau dikenal dengan istilah erosi dan kebanyakan tindakan organisme akan membentuk muka bumi, tetapi dalam proses yang sama juga merendahkan muka bumi. Di sisi lain agradasi atau pengendapan akan mengisi lekuk atau cekungan yang terdapat di permukaan bumi.

2. Proses Endogen

Proses endogen berpusat dari dalam bumi, termasuk aktivitas volkanisme gunungapi yang berupa letupan, aliran lava, awan panas dan gas. Dalam proses endogen yang didukung dengan proses eksogen akan menimbulkan lipatan-lipatan sesar. Akibat dari adanya proses endogen ini akan menukar bentuk dan kedudukan bagian kerak bumi, sementara gempa bumi sudah dianggap sebagai salah satu proses diastrofisme yang terdiri dari dua cara, yaitu runtuhan (collapse) dan penyesaran sesar, sehingga gempa bumi yang demikian akan menghasilkan morfologi.

\section{Proses dan Agen Geomorfologi}




\begin{tabular}{|c|c|}
\hline Proses & Agen \\
\hline $\begin{array}{l}\text { EKSOGEN } \\
\begin{array}{l}\text { 1. Degradasi } \\
\bullet \text { erosi } \\
\bullet \text { susutan darat }\end{array}\end{array}$ & $\begin{array}{ll}- & \text { air mengalir } \\
- & \text { air bawah tanah } \\
- & \text { air laut } \\
- & \text { angin } \\
& \text { glasier }\end{array}$ \\
\hline 2. Degradasi & $\begin{array}{ll}- & \text { air mengalir } \\
- & \text { air bawah tanah } \\
- & \text { air laut } \\
- & \text { angin } \\
& \text { glasier }\end{array}$ \\
\hline 3. Tindakan organisma & $\begin{array}{ll}- & \text { manusia } \\
- & \text { hewan } \\
\text { - } & \text { tumbuh-tumbuhan }\end{array}$ \\
\hline $\begin{array}{l}\text { ENDOGEN } \\
\text { 1. Vulkanisme (gunung berapi) }\end{array}$ & $\begin{array}{ll}- & \text { magma, lava } \\
- & \text { piroklas } \\
& \text { awan panas, gas }\end{array}$ \\
\hline $\begin{aligned} & \text { 2. Diastrofisme : } \\
& \\
&$\[ \text { pengangkatan } \]$ \\
& \bullet \text { penurunan } \\
& \text { pelipatan } \\
& \text { peretakan dan penyesaran }\end{aligned}$ & \\
\hline 4. Gempa bumi & \\
\hline
\end{tabular}

Sumber : Tjia, H.D. 1987

Dalam kaitannya dengan keperluan rekonstruksi lingkungan masa lalu sangat diperlukan suatu data yang berkaitan dengan pemanfaatan dan pemahaman seseorang tentang sumberdaya alam. Bentuk data lingkungan meliputi segala materi komponen lingkungan, baik fisik maupun maupun biotik, antara lain iklim, geologi, tanah, vegetasi, dan flora-fauna. 
Desa Sambisari, Kalurahan Purwomartani, Kecamatan Kalasan secara geografis terletak pada lereng selatan bagian bawah dari Gunung Merapi, dengan jarak lebih kurang $18 \mathrm{~km}$. Oleh karenanya, pengaruh dari aktivitas gunung tersebut masih sangat terasa. Di sebelah barat lokasi candi Sambisari, pada jarak 300 meter mengalir Sungai Kuning yang berasal dari daerah sekitar Kinahrejo, sebelah timur laut Kaliurang. Sungai kuning tersebut mempunyai arti yang cukup penting terhadap tertimbunnya Candi Sambisari.

\section{KABUPATEN SLEMAN}

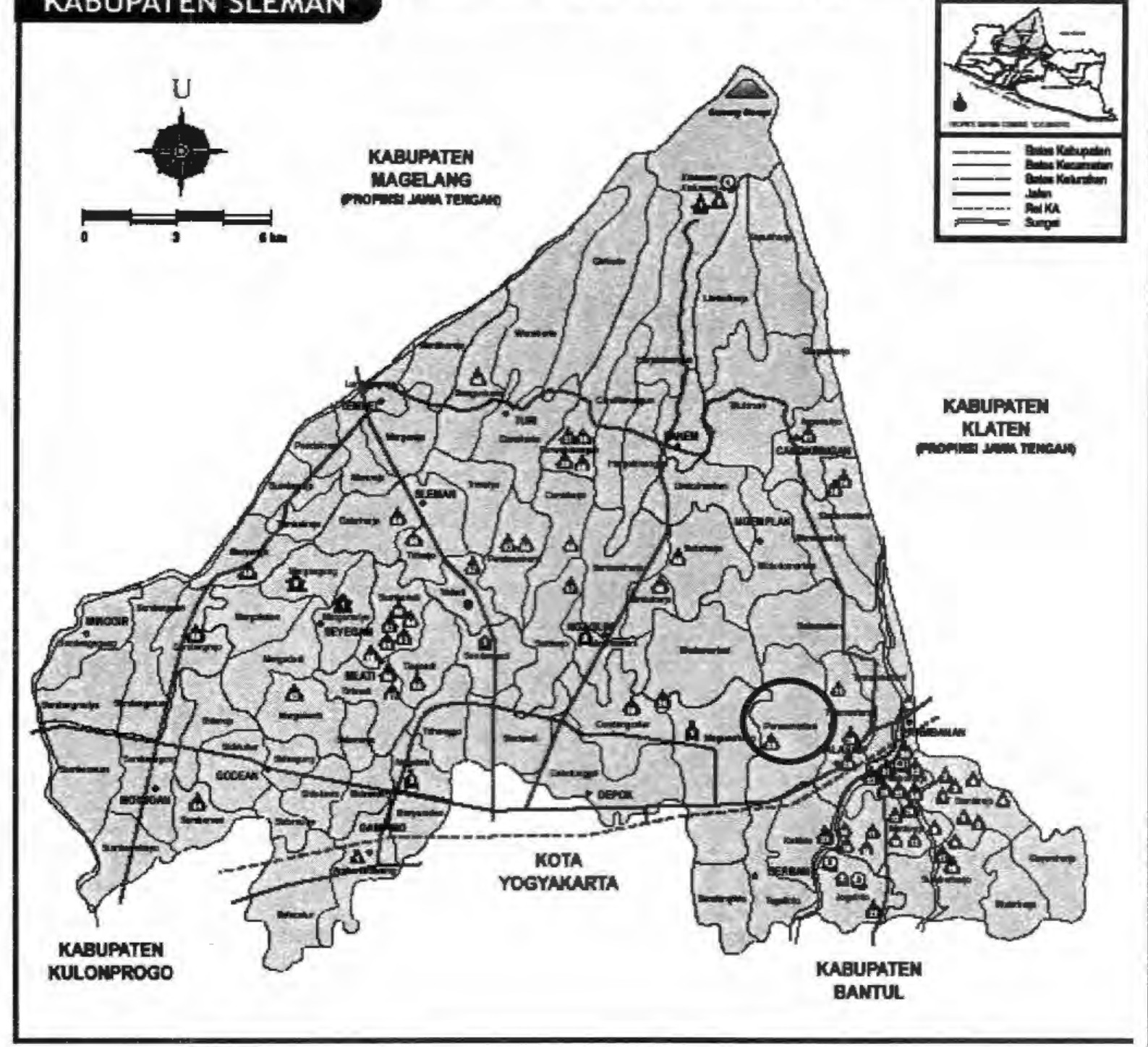

Lokasi situs Candi Sambisari dalam

peta sebaran situs caga budya di Kab. Sleman

Sumber: Dinas Pariwisata Prop. DIY 
Di Situs Sambisari, tanah endapannya berasal dari bahan induk endapan lahar dan endapan fluvial hasil rombakan bahan piroklastik letusan Gunungapi Merapi berupa boulder, gravel, pasir, dan debu. Sedangkan perkembangan tanah di sekitar Situs Sambisari masih dalam taraf awal (initial stage) yang termasuk jenis tanah regosol horison dan tanah ini belum mengalami diferensiasi horison, sehingga profil tanahnya homogen. Sifat tanah semacam ini dapat diamati melalui tekstur pasir berdebu hingga pasir debu berkerikil.

Kali Kuning merupakan salah satu sungai yang dapat terancam oleh bahaya aliran lahar hujan, sehingga daerah di sekitar Situs Candi Sambisari pun merupakan daerah yang dapat terancam oleh aliran lahar. Hal tersebut terbukti dengan pernah tertimbunnya Candi Sambisari oleh endapan material volkanik, sebagai akibat dari letusan Gunung Merapi, sebagaimana disebutkan oleh Van Bemmelen di atas. Di samping itu, Kali Kuning merupakan sungai sesar, karena mengikuti garis sesar yang terjadi di sayap selatan Gunung Merapi dan di sepanjang garis sesar pada umumnya merupakan daerah yang potensial terhadap gempa yang berpotensi untuk meruntuhkan berbagai bangunan.

Berdasarkan laporan sepuluh tahun ekskavasi Candi Sambisari, 1976, bahwa secara keseluruhan bangunan Candi Sambisari telah hancur, kecuali hanya beberapa bagian dari bangunan yang ada. Bangunan atap candi telah hancur dan ditemukan dalam tanah pada kedalaman yang bervariasi. Beberapa bagian dari badan candi ditemukan sudah banyak yang lepas dalam kondisi terpendam dalam tanah di sekitar bangunan tubuh candi yang belum rusak. Candi perwara ditemukan dalam kondisi berserakan. Pagar dinding luar di sisi barat, pada beberapa bagian sudah lepas dalam bentuk fragmen dan tidak ditemukan. Batu-batu bagian dari atap gapura berserakan dan tidak ditemukan batu-batu bagian dari atap bangunan candi (Soediman, 1976).

\section{Morfologi dan Sifat Relief Lingkungan Situs Candi Sambisari}

Sejarah morfologi Pulau Jawa berawal dari masa pliosen yang memungkinkan terjadinya tiga lajur geologis yang membentang sejajar dengan poros barat-timur pulau tersebut. Di Lajur Selatan (daerah tepi Samudera Hindia) ditemukan endapan-endapan yang tertua, yaitu endapan eosen dan endapan oligosen. Akan tetapi, pada bagian terbesar dari bentangan ini terdiri dari endapan miosen, batu breksi dan tufa andesit atau batu kapur, ketinggian tanah rata-rata tidak melebihi 1000 meter, tetapi pada bagian pantainya kebanyakan berkarang, bertebing-tebing tinggi lagi curam dan lautnya sangat berbahaya.

Lajur yang ke dua adalah lajur tengah yang secara hakiki bersifat volkanis, sedimen-sedimen miopliosen yang membentuk lapisan-lapisan tanah yang hampir seluruhnya tertutup oleh relief bentukan dari deretan gunungapi yang terdiri lebih 
dari 100 buah, 14 diantaranya berketinggian lebih dari 3000 meter dan 25 di antraranya masih aktif dengan letusan-letusannya yang berturut-turut, sehingga menyebabkan tertimbunnya tumpukan lava dan bahan-bahan lain yang terlontar keluar yang kemudian disebarluaskan oleh aliran-aliran lain yang lebih kecil, sehingga menutupi permukaan daerah di sekelilingnya.

Kemudian, lajur yang ke-tiga adalah lajur utara yang berbatasan dengan Laut Jawa, yaitu merupakan dasar lipatan lembah kulit bumi (geosinklin) yang menyembul di atas permukaan. Di sebelah barat daerah ini terdiri atas dataran rendah yang sangat luas, yaitu dataran Jakarta dan sekitarnya. Di bagian tengah dan timur terdiri atas dataran-dataran yang lebih kecil yang diselingi oleh bukitbukit yang arahnya dari barat-timur hingga berlanjut ke Madura.

Struktur relief Pulau Jawa tampak tidak semasif dengan Sumatera. Kenyataan yang menonjol di Jawa adalah volkanisme, tetapi kerucut gunung di Jawa pada umumnya muncul di atas dataran. Perbedaan lain yang menonjol adalah jumlah gunungapi di Jawa lebih banyak dan lebih muda dibanding gunungapi di Sumatera. Jawa memiliki 121 gunung api, sedangkan Sumatera memiliki 90 buah dan sebagian besar gunungapi di Jawa masih aktif (Lombard, 2000).

\section{A. Morfologi Situs Candi Sambisari}

Gunungapi Merapi, dengan ketinggian sekitar 2911 meter dari muka air laut, secara morfologis merupakan gunungapi strato yang berbentuk suatu kerucut besar dengan muatan basalt dan andesit. Bagian puncak terdapat kandungan material lepas sebagai hasil erupsi yang masih baru dengan ukuran pasir sampai bongkah dengan komposisi andesit piroksen dan andesit horenblende.

Hasil erupsi saat ini berupa kubah lava, pasir dan abu volkanik yang cenderung mengalir ke arah barat, barat daya, dan sedikit kearah selatan melalui lembah-lembah sungai. Kerucut Gunungapi Merapi ini semakin melandai ke segala arah. Ke arah selatan telah menghasilkan bentuk morfologi bukit-bukit memanjang ke arah selatan dengan pola mirip tapal kuda serta melebar ke bagian yang lebih rendah. Bentuk morfologi yang demikian itu, di daerah Sambisari sudah merupakan bentuk dataran miring dan sedikit bergelombang yang disebabkan oleh banyaknya alur sungai-sungai kecil. Bentuk alairan sungai yang masih lurus dan mengikuti lereng yang curam cenderung membentuk tipe sungai teranyam, artinya alur-alur sungai cenderung mudah berpindah tempat dari waktu ke waktu sebagai akibat dari lereng curam, sehingga menghasilkan banyak alur yang saling berpotongan. Tipe sungai yang demikian itu antara lain disebabkan oleh seringnya alur sungai dialiri oleh lahar hujan yang bersifat merusak, sehingga dari 
kecepatannya yang cukup tinggi menyebabkan arah alirannya menyimpang dari alur yang asli kemudian membentuk alur yang baru.

Curah hujan di puncak merapi rata-rata setiap tahunnya cukup tinggi, yaitu hampir mencapai $4000 \mathrm{~mm}$. Tingginya curah hujan tersebut sering mengakibatkan terbentuknya lahar hujan yang biasa terjadi setiap saat. Namun demikian, bahaya lahar hujan yang demikian masih tergolong pada bahaya sekunder, karena hal ini terjadi pada waktu hujan turun dengan lebat, di daerah sekitar puncak Gunungapi Merapi membawa material hasil erupsi yang masih lepas dan bisa terjadi pada saat-saat tidak terjadi erupsi letusan. Sedangkan bahaya primer, adalah bahaya yang ditimbulkan secara langsung karena terjadinya letusan, berupa aliran lava, batu, pasir, dan awan panas yang meluncur dengan cepat dengan suhu yang sangat tinggi. Sehingga pada saat sekarang, daerah yang berpotensi untuk bahaya primer disebut sebagai daerah terlarang (Toha, 1986).

B. Sifat Relief Lingkungan Situs Candi Sambisari

Budio Basri, (1989) menjelaskan, bahwa Jawa adalah salah satu dari gugusan pulau yang terdapat di Indonesia yang memiliki sifat fisiografi yang khas yang antara lain disebabkan oleh iklim tropis. Di samping itu ciri-ciri geografinya disebabkan oleh geosinklinal muda dan jalur orogenesa dengan banyak volkanisme yang kuat, sehingga berakibat Jawa berbentuk panjang dan sempit. Sifat relief yang disebabkan oleh iklim tropis terlihat pada banyaknya curah hujan dan temperatur yang tinggi, sehingga mengakibatkan terjadinya pelapukan yang cepat dan intensif, serta denudasi yang diikuti oleh erosi vertikal.

Perbedaan topografi yang disebabkan oleh adanya perbedaan batubatuannya, bila dibandingkan dengan daerah yang iklimnya berbeda, kurang tampak jelas, meskipun lembah yang kecil memiliki tebing yang curam. Hal itu berakibat banyaknya curah hujan dan banyak air yang harus mengalir, hingga banyak terjadi parit alam yang cukup rapat yang mengakibatkan topografinya terkikis. Akibatnya sisa permukaan yang dulu pernah terangkat akan hilang dalam waktu yang singkat.

Sementara itu, Gunungapi Merapi adalah gunungapi yang aktif dan merupakan kerucut gunungapi muda. Gunungapi Merapi ini sering dilakukan penyelidikan, karena gunung ini memiliki sifat-sifat peletusan yang sangat merusak, yaitu pada waktu sumbat lava mengisi kawah dan nuees ardentes mengalir ke bawah melalui lerengnya. Lereng yang terdapat di sebelah timur dan beberapa lereng yang 
terdapat di sebelah selatan termasuk tipe yang tua. Menurut Van Bemmelen, ketika proses tersebut berlangsung (pada waktu sumbat lava mengisi kawah dan nuees ardentes mengalir ke bawah melalui lerengnya), bagian yang lain menggelincir ke bawah dan mengakibatkan bukit-bukit yang terdapat pada kaki sebelah barat daya mengalami gerak lipatan, kemudian Gunungapi Merapi yang sekarang ada ini tumbuh di tempat bagian yang runtuh dari bagian gunung yang lebih tua. Gunungapi Merapi dan Gunung Merbabu merupakan bagian dari gunungapi yang berada di jalur melintang yang letaknya paling selatan. Gunung Merbabu merupakan gunung yang lebih tua daripada Gunungapi Merapi muda. Lembah radial yang terdapat di Gunung Merbabu lebih dalam dan lebih curam daripada lembah radial yang terdapat di Gunungapi Merapi. Hal ini disebabkan oleh kuatnya erosi dan adanya pengaruh gerak tektonik (Fannekoek, 1949).

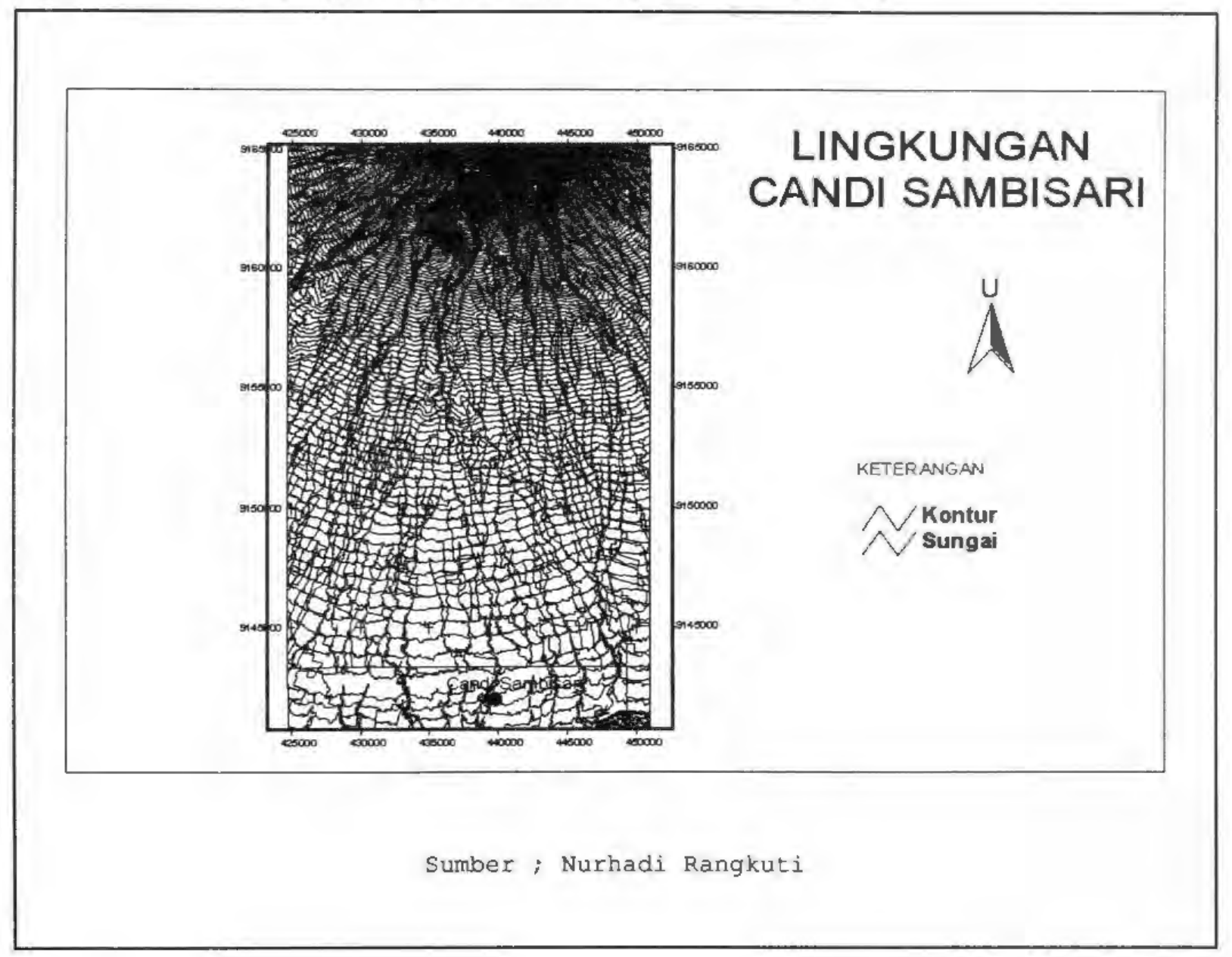

Tjia, H.D, (1987) menjelaskan bahwa antiklin dan sinklin sering dijumpai di Pulau Jawa dan umumnya sebagai hasil dari longsoran graviti. Longsoran tersebut berlangsung akibat keluaran gunungapi 
semakin banyak tertimbun di atas sedimen tersier lembut yang berada di bawahnya dan menjadikan gunungapi tersebut menerima beban semakin berat, sehingga berakibat terjadinya longsoran. Aliran lava dan aliran lumpur akan mengganggu sistem aliran di kawasan gunung berapi. Pada gunungapi yang masih muda, pengempangan dan pengalihan sungai lebih merupakan fenomena morfologi yang agak lazim pada gunungapi di Jawa (Tjia, H.D. 1987 : 111-112).

Dilihat dari asal material batuannya, daerah Sambisari merupakan lahan yang sangat memungkinkan untuk memperoleh pasokan material dari Gunungapi Merapi, karena Gunungapi Merapi merupakan salah satu gunung di Jawa yang sampai sekarang masih menunjukkan keaktifannnya. Gunungapi Merapi tersebut tumbuh dan berkembang pada suatu persilangan antara sesar melintang dan sesar membujur yang membelah pula (Verstappen, 1988). Tetapi, menurut Van Bammelen (1970), sesar melintang dengan arah utara-selatan adalah yang memisahkan antara Jawa Timur dan Jawa Tengah, sedangkan lintang membujur ke arah timur-barat adalah yang membentuk batas antara perbukitan Kendeng bagian barat dan subzone Ngawi. Kemudian Gunungapi Merapi yang meletus pada tahun $1006 \mathrm{M}$ dengan dahsyat, hingga memusnahkan penduduk dan memporak-porandakan kerajaan Hindu yang makmur di Jawa Tengah juga telah mengakibatkan lahan subur di sekitar Gunungapi Merapi tersebut menjadi lahan yang tertutup oleh abu volkanik. Erupsi Katastrofik Gunungapi Merapi pada tahun 1006 tersebut sebagai akibat adanya gabungan tiga jenis tenaga alam, yaitu tenaga tektonik, tenaga volkanik, dan gravitasi (Bemmelen, 1970).

Tenaga tektonik merupakan gerakan pemicu rusaknya kerucut Gunungapi Merapi, tenaga grafitasi merupakan gerakan yang menyebabkan peruntuhan dan penggelinciran sebagian besar kerucut Gunungapi Merapi ke arah barat (ke lembah Progo), dan tenaga volkanik menyebabkan ledakan katastrofik yang sangat dahsyat. Dari gabungan tiga tenaga tersebut menyebabkan kerucut Gunungapi Merapi mengalami sesar-gelincir hiperbolik yang cekung ke arah barat. 


\section{Kesimpulan}

Dari uraian tersebut di atas dapat disimpulkan, bahwa secara geomorfologis Situs Candi Sambisari terletak di dataran aluvial kaki Gunungapi Merapi, sehingga tanahnya subur, mudah memperoleh air dan lahannya cocok untuk bermukim dan pertanian. Alasan inilah yang sangat memungkinkan untuk didirikannya bangunan candi. Akan tetapi, karena kemudian daerah lokasi situs tersebut tertutup oleh abu volkanik sebagai akibat letusan Gunungapi Merapi yang sangat dahsyat karena adanya gabungan dari tiga tenaga tektonik, gravitasi dan volkanik hingga menyebabkan kerucut Gunungapi Merapi mengalami sesar-gelincir hiperbolik yang cekung, maka hal tersebut berakibat tingkat kesuburan tanah di sekitar Situs Candi Sambisari berkurang bahkan menjadi rusak, karena berdasarkan material tanah endapannya berasal dari bahan induk endapan lahar dan endapan fluvial hasil rombakan bahan piroklastik letusan Gunungapi Merapi berupa boulder, gravel, pasir, dan debu. Sedangkan perkembangan tanah di sekitar Situs Sambisari masih dalam taraf awal (initial stage) yang termasuk jenis tanah regosol horison dan tanah ini belum mengalami diferensiasi horison, sehingga profil tanahnya homogen. Sifat tanah semacam ini dapat diamati melalui tekstur pasir berdebu hingga pasir debu berkerikil.

Di sisi lain, daerah Sambisari dan lingkungannya merupakan lahan yang sangat memungkinkan untuk memperoleh pasokan material dari Gunungapi Merapi, karena Gunungapi Merapi merupakan salah satu gunungapi di Jawa yang sampai sekarang masih menunjukkan keaktifannnya. Hal demikian didukung oleh keberadaan Kali Kuning yang mengalir di sebelah barat Situs Candi Sambisari pada jarak sekitar 300 meter. Kali Kuning tersebut merupakan salah satu sungai yang dapat terancam oleh bahaya aliran lahar hujan, sehingga daerah di sekitar Situs Candi Sambisari pun merupakan daerah yang dapat terancam oleh aliran lahar. Di samping itu Kali Kuning merupakan sungai sesar, karena mengikuti garis sesar yang terjadi di sayap selatan Gunungapi Merapi, dan di sepanjang garis sesar pada umumnya merupakan daerah yang potensial terhadap gempa yang berpotensi untuk meruntuhkan berbagai bangunan.

Kemudian mengenai geomorfologi di lingkungan Situs Candi Sambisari, terdapat dua macam proses yang termasuk salah satu sebab rusaknya lingkungan Situs Candi Sambisari, yaitu proses eksogen yang terdiri dari degradasi, agradasi dan tindakan organisma yang didukung oleh proses endogen yang bersumber dari dalam bumi, termasuk aktivitas volkanime gunungapi yang berupa letupan, aliran lava, awan panas, dan gas. Dalam proses endogen yang didukung dengan proses eksogen demikian, akan menimbulkan lipatan-lipatan sesar.

Lingkungan Situs Candi Sambisari memiliki sifat relief yang disebabkan oleh iklim tropis yang terlihat pada banyaknya curah hujan dan temperatur yang tinggi, 
sehingga mengakibatkan terjadinya pelapukan yang cepat dan intensif, serta denudasi yang diikuti oleh erosi vertikal. Perbedaan topografi yang disebabkan oleh adanya perbedaan batu-batuannya, bila dibandingkan dengan daerah yang iklimnya berbeda, kurang nampak jelas, meskipun lembah yang kecil memiliki tebing curam. Hal itu mengakibatkan banyak curah hujan dan banyak air yang harus mengalir, sehingga terjadi parit alam yang cukup rapat dan topografinya terkikis.

\section{DAFTAR PUSTAKA}

Fannekoek, A.j. 1949. Out line of the Geomorphology of Java. (Alih bahasa: Basri, Budio, 1989). Garis Besar Geomorfologi Pulau Jawa.

Anonim. 1989. Pemugaran Candi Brahma Prambanan, Candi Sambisari, Taman Narmada, Departemen Pendidikan dan Kebudayaan, Jakarta.

Bemmelen, R.W. 1970. The Geology of Indonesia, Vol. IA General Geology of Indonesia and Adjacent Archipelagoes, edisi ke-2. The Hague-Martinus Nijhoff.

Damon, Albert. 1977. Human Biology and Ecology. W.W. Norton and Company, New York.

Hardesty, Donald L. 1980. The Use of General Ecological Principles in Archaeological. Dalam M.B. Schiffer Advances in Archaeological Method and Theory.

Ibnu Thufail, Fajar. Pendekatan Lingkungan dalam Teori Kebudayaan. Media Komunikasi Artefak, No. 14. Yogyakarta.

Kusumohartono, B. M. (1985). Pendekatan Lingkungan Dalam Rekonstruksi Pertumbuhan Pemukiman Trowulan Kuna: Suatu Pemikiran Induktif. Berkala Arkeologi, 6(1), 56-66. https://doi.org/10.30883/jba.v6i1.436

White, Leslie A. 1959. The Evolution of Culture. Mc. Graw Hill Co, New York.

Lombard, Denis. 2000. Nusa Jawa Silang Budaya, Vol. 1, Batas-Batas Pembaratan. Gramedia Pustaka Utama, Jakarta.

Steward, Julian, H. 1955. Theory of Cultural Change: The Methodology of Multilinier Evolution. Urbana University of Illinois Press. 
Mc. Naughton, S.J. dan Wolf, Larry L. 1990. Ekologi Umum. Gadjah Mada University Press, Yogyakarta.

Mundardjito. 1993. Pertimbangan Ekologi dalam Penempatan Situs Masa HinduBudha di Daerah Istimewa Yogyakarta, Kajian Arkeologi Ruang Skala Makro. Desertasi. Program Pascasarjana, Universitas Indonesia, Jakarta.

Resosoedarmo, S. Kuswata Kartawinata dan Apriliani Soegiarto. 1984. Pengantar Ekologi. Remaja Karya, Bandung.

-, 2002, Arkeologi Keruangan, Konsep dan Cara Kerjanya dalam Kumpulan Makalah Pertemuan Ilmiah Arkeologi VIII. Ikatan Ahli Arkeologi Indonesia, Jakarta.

Schiffer, Michael, B. 1986. Advance In Archaological Method And Theory Vol. 3.

Soediman. 1976. Laporan Sepuluh Tahun Ekskavasi Candi Sambisari. Yayasan Purbakala, Yogyakarta.

Soeriaatmadja, R.E. 1979. Ilmu Lingkungan. Penerbit ITB, Bandung.

Soeryani, Mohamad. 1986. Ekologi Pengelolaan Sumberdaya Alam dan Industrialisasi. Prisma No. LP3ES, Jakarta.

Shackley, M. 1981. Environmental Archaeology, George Allen \& Unwin, London, Boston, Sydney.

Sutikno. 2002. Terapan Geomorfologi untuk Kajian Arkeologi, Beberapa Hasil Penelitian di Berbagai BentukJahan. Pertemuan Ilmiah Arkeologi VIII. Ikatan Ahli Arkeologi Indonesia, Jakarta.

Tjia, H.D. 1987. Geomorfologi. Dewan Bahasa dan Pustaka, Kementerian Pendidikan Malaysia, Kuala Lumpur.

Verstappen, H. Th. 1988. Excurtion Guide Pre-26 th, International Geographical Congress, Simposium Working Group on Geomorfological Surveying and Mapping. Faculty of Geography. Gadjah Mada University, Yogyakarta. 